\title{
PERIODICALS
}

\section{ENGINEERING RESEARCH}

Advanced Engineering Forum (/AEF/details)

Journal of Biomimetics, Biomaterials and Biomedical Engineering (/JBBBE/details)

Advances in Science and Technology

(/AST/details)

Applied Mechanics and Materials

(/AMM/details)

International Journal of Engineering Research in Africa (/JERA/details)

Foundations of Materials Science and Engineering (/FoMSE/details)

\section{MATERIALS} SCIENCE

\section{Journal of Metastable and Nanocrystalline Materials (/JMNM/details) Journal of Nano Research}

Home (/) > Applied Mechanics and Materials (/AMM) (/APetailss)

\section{Applied Mechanics and Materials}

ISSN: 1662-7482

\begin{tabular}{cccc}
\hline $\begin{array}{c}\text { Volumes } \\
\text { (/AMM) }\end{array}$ & My & Details & Editorial \\
& eBooks & (/AMM/detalios)ard \\
& (/AMM/ebooks) & (/AMM/editor
\end{tabular}

About: "Applied Mechanics and Materials" is a peer-reviewed journal which specializes in rapid publication of proceedings of international scientific conferences, workshops and symposia as well as special volumes on topics of contemporary interest in all areas which are related to:

1) Research and design of mechanical systems, machines and mechanisms;

2) Materials engineering and technologies for manufacturing and processing;

3) Systems of automation and control in the areas of industrial production;

4) Advanced branches of mechanical engineering such as mechatronics, computer engineering and robotics.

"Applied Mechanics and Materials" publishes only complete volumes on given topics, proceedings and complete special topic volumes. We do not publish stand-alone papers by individual authors.

Authors retain the right to publish an extended, significantly 


\section{(/JNanoR/details)}

Defect and Diffusion

Forum (/DDF/details)

Solid State Phenomena

(/SSP/details)

Diffusion Foundations

(/DF/details)

Materials Science

Forum (/MSF/details)

Key Engineering

Materials

(/KEM/details)

Nano Hybrids

(/NH/details)

Advanced Materials

Research

(/AMR/details)

\section{LIMITED}

\section{COLLECTIONS}

\section{Specialized Collections} (/SC/details)

Retrospective

Collection

(/RC/details) updated version in another periodical.

Indexing: indexed by

Index Copernicus Journals Master List

www.indexcopernicus.com.

Google Scholar scholar.google.com.

Chemical Abstracts (CAS) www.cas.org.

Cambridge Scientific Abstracts (CSA) www.csa.com.

Inspec (IET, Institution of Engineering Technology)

www.theiet.org.

SCImago Journal \& Country Rank (SJR) www.scimagojr.com.

ProQuest www.proquest.com.

EBSCO www.ebsco.com.

Zetoc zetoc.jisc.ac.uk.

CiteSeerX citeseerx.ist.psu.edu.

Thomson Reuters (WoS), all volumes are submitted and selected ones will be indexed.

Additional Information:

Please ask for additional information:

amm@scientific.net (amm@scientific.net )

Subscription: Irregular: approx. 30-50 volumes per year.

The subscription rate 2016 for web access is EUR 1089.00 per year.

Standing order price: $20 \%$ discount off list price(see here) (http://scientific.net/Downloads).

ISSN print 1660-9336 ISSN cd 1660-9336 ISSN web 16627482

Share:

Main Themes published in this Periodical (/AMM)

\section{Useful}

\section{Links}

SUBSCRIPTIONS

- Advanced Manufacturing Technologies

(/AMM.834)

(/ACCOUNT/SUBSCRIPTIONSAdvanced Engineering Forum Vol. 16 (/AEF.16)

FOR EDITORS (/INFO)

LOG IN

(/ACCOUNT/LOGON?

- Structure and Properties of Building Materials (/FoMSE.91)
Scientific. Net is a registered brand of Trans Tech

Publications Inc.

2016 by Trans Tech

Publications Inc. All Rights

Reserved

RETURNURL $=\% 2$ FAMM $\% 2$ FDETAILS)

MY CART 
(/PAYMENT/CART)

SEARCH

(/PAPERSSEARCH.ASPX)

CONTACT US

(/HOME/CONTACTS)

TERMS AND

CONDITIONS

(/HOME/TERMSANDCONDITIONS)

POLICY AND ETHICS

(/HOME/POLICYANDETHICS)

CONFERENCE ETHICS

AND QUALITY

CONTROL

(/HOME/CONFERENCEETHICSANDQUALITYCONTROL)

DISTRIBUTORS

(/DISTRIBUTOR)

DOWNLOADS

(/DOWNLOADS)

ABOUT US

(/HOME/ABOUTUS)

SITEMAP

(/HOME/SITEMAP) 


\section{Home}

Journal Rankings

\section{Journal Search}

Country Rankings

\section{Country Search}

Compare

\section{Map Generator}

$$
\text { Help }
$$

About Us

\section{Show this information in} your own website

\section{Applied Mechanics and}

\section{Materials}

Indicator 2007-2014 Value
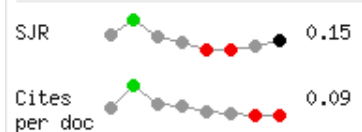

per doc

Total

cites

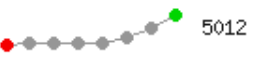

wuw.scimagojr.com

Display journal title

Just copy the code below and paste within your html page: <a href="http://www.scimagojr.com

Related product

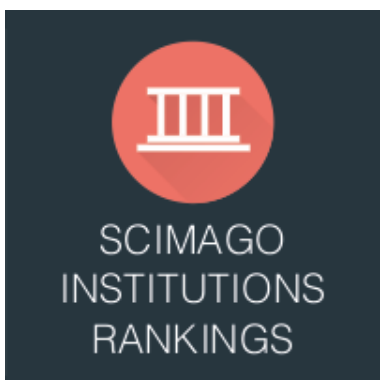

@scimago

SJR is developed by:

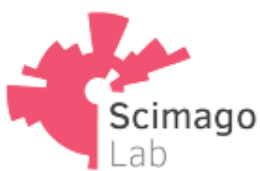

\section{Journal Search}

Search query

\section{in Journal Title $\mathbf{v}$ Search}

$\square$ Exact phrase

Applied Mechanics and Materials

Country: Germany

Subject Area: Engineering

Subject Category:

\section{Category}

Quartile (Q1 means highest values and Q4 lowest values)

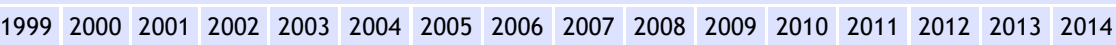

Engineering

(miscellaneous)

Publisher: Trans Tech Publications. Publication type: Book Series. ISSN: 16627482, 16609336

Coverage: 2005-2015

H Index: 15
The SJR indicator measures the scientific influence of the average article in a journal, it expresses how central to the global scientific discussion an average article of the journal is. Cites per Doc. (2y) measures the scientific impact of an average article published in the journal, it is computed using the same formula that journal impact factor ${ }^{\mathrm{T}}$ (Thomson Reuters).

\section{Citation vs. Self-Citation}




\title{
The Effect of Nitrogen on Flame Characteristics in Biogas External Premixed Combustion
}

\author{
Willyanto Anggono ${ }^{1, a}$, Fandi Dwiputra Suprianto ${ }^{2}$, Kenny Purnomo ${ }^{3}$, \\ Tan Ivan Hartanto ${ }^{4}$ and Tubagus P. Wijaya ${ }^{5}$ \\ 1,2,3,4,5 Mechanical Engineering Department, Petra Christian University, Surabaya, Indonesia \\ awilly@petra.ac.id
}

\begin{abstract}
Keywords: Biogas, nitrogen, external combustion, sustainable energy, flame characteristics.
\end{abstract}

\begin{abstract}
Biogas contains more than 50\% methane $\left(\mathrm{CH}_{4}\right)$, is a renewable and eco-friendly fuel produced by bacterial action. Not only is biogas flammable but it also contains inhibitors like carbon dioxide and nitrogen, as well as small amounts of $\mathrm{H}_{2}, \mathrm{O}_{2}, \mathrm{H}_{2} \mathrm{~S}$ and others. Several associated studies have been conducted in order to examine biogas combustion characteristics in external combustion and flame angle, flame height and dimensionless flame height are the important characteristics in external premixed combustion. This research's aims were to discover the influences of $\mathrm{N}_{2}$ as it is the second most prevalent inhibitor in biogas by burning stoichiometric fuel mixtures $\left(\mathrm{CH}_{4}\right.$ and $\mathrm{N}_{2}$ ( $0 \%-50 \%$ of fuel)) and oxygen in an experimental external premixed combustion burner whose nozzle tip diameter was $5 \mathrm{~mm}$. The burner was connected to a hose from the oxygen tank and another hose from the fuel tank. Two regulators and flowmeters were placed on each tank to monitor the flow supplied to the mixer and burner. The valves were used to stop or open the fluid supply. The outcome flame propagation is then recorded by a high speed camera and then processed through a computer system. The results indicate that $\mathrm{N}_{2}$ influenced the flame angle, flame height and dimensionless flame height. The higher the $\mathrm{N}_{2}$ content inside the fuel, the shorter the flame height and the lower the dimensionless flame height. Moreover, increasing the $\mathrm{N}_{2}$ content created larger the flame angle.
\end{abstract}

\section{Introduction}

A research, which directs on the impact of carbon dioxide $\left(\mathrm{CO}_{2}\right)$ as an inhibitor in pure methane $\left(\mathrm{CH}_{4}\right)$ combustion, was conducted by utilizing a burner in which is composed of a stainless mesh to stabilize the flame and perforated plates to generate a turbulent premixed flow. The experiment utilized a nozzle burner to combust the mixtures, then the flame characteristics were examined with a laminar burning velocity formula [1-3].

Several studies and experiments have been conducted in the field of the combustion characteristics of alternative fuels and have tested the effects of air fuel ratios (AFR) on combustion characteristics of LPG and methane [4-7]. Also, in constant volume combustion bomb explosions, combustion characteristics and flame propagation of methane-air mixtures were studied by analyzing the flame propagation images, the combustion stability at various equivalence ratios of nitrogen to gas mixture. Furthermore, the effects of initial pressure on the flame propagation and combustion characteristics were studied too. It was noted that the laminar flame velocity decreased with the increase of nitrogen fraction in the gas mixture. If the nitrogen fraction in the gas mixture surpasses $20 \%$, the flame will be unstable and is easily extinguished (Liang et al.) [8].

An experiment using a coaxial burner showed that the absence of nitrogen or carbon dioxide in propane-oxygen gives a bright blue flame. The greater the concentration of those inhibitors in the propane-oxygen, the dimmer the blue in it and the more the flame yellowish it became. By increasing the nitrogen or carbon dioxide percentage in oxygen-methane mixtures, the flame length enhances gradually. This study showed that carbon dioxide and nitrogen caused lift-off and blow-out, which meant that the inhibitors affected flame stability [9].

In addition, in other studies have used different burner and one of which used some porous radiant burners, commonly used in LPG burning, to observe flame characteristics, emissions and thermal efficiency. It found that the flame produced in a McKenna burner, compared to the other burners, was flat and caused the temperature distribution to become uniform, despite the variation in the burners. 
Another study looked at the effects of experimental models that used, varying flame nozzle lengths and width on the outcome of flame heights (F. Migliorini et al., C.Y. Wu et al., S. Osami, et al.) [10-12].

Biogas is an alternative renewable fuel obtained from the excrement of animals and humans and is mainly composed of methane (more than 50\%). Biogas also contains inhibitors like carbon dioxide and nitrogen, as well as small amounts of $\mathrm{H}_{2}, \mathrm{O}_{2}$, and $\mathrm{H}_{2} \mathrm{~S}$ but biogas composition varies depending on its origin. Methane $\left(\mathrm{CH}_{4}\right)$ is a combustible organic compound but carbon dioxide $\left(\mathrm{CO}_{2}\right)$ and nitrogen $\left(\mathrm{N}_{2}\right)$ content are inert, which do not react in combustion. Furthermore, biogas contains other substances such as: hydrogen, hydrogen sulfide, oxygen, nitrogen and others. The calorific values of biogas largely depend on its methane content [13-17].

Biogas combustion has been the subject of much research in the last two decades and several late studies have reported important results on the burning characteristics of spark ignited premix combustion. At sundry equivalence ratios, some laminar burning velocities and the series of flammability limits of biogas-air internal premixed combustion were observed experimentally. All of these studies found that the flame characteristics of biogas are mainly dependent on the degree of its main inhibitor, which is $\mathrm{CO}_{2}$. In addition, the research using various combustion chamber in order to verify the effects of $\mathrm{CO}_{2}$ on biogas internal premixed combustion found that increasing $\mathrm{CO}_{2}$ level in biogas lowers the burning velocity of internal premixed biogas combustion (W. Anggono et al.) [13-17]. Because of examining a flame height produced from a particular nozzle diameter, it is important that dimensionless flame height be plotted. Dimensionless flame height is important flame characteristic in the external premixed combustion and it is a parameter of flame height without considering the nozzle tip diameter. So, the independence data can be obtained [18].

The aim of this research was to study the effects of $\mathrm{N}_{2}$ as the second largest inhibitor in biogas on external premixed combustion. Flame angle, flame height and dimensionless flame height are important parameter in flame characteristics. Hence, the main objective of this study was to explore the influence of $\mathrm{N}_{2}$ on the formation of flame angle, flame height and dimensionless flame height.

\section{Experiment Methods}

The experiments were conducted at the Thermal and Fluid Laboratory, Mechanical Engineering Department, Petra Christian University, Surabaya, Indonesia. The variables were various percentages of Nitrogen in fuel $\left(\mathrm{CH}_{4}-\mathrm{N}_{2}\right.$ mixtures), namely, $0 \%, 10 \%, 20 \%, 30 \%, 40 \%$ and $50 \%$ respectively. Each of concentration was stored inside a tank. The details of the experiment design are shown in Fig. 1.

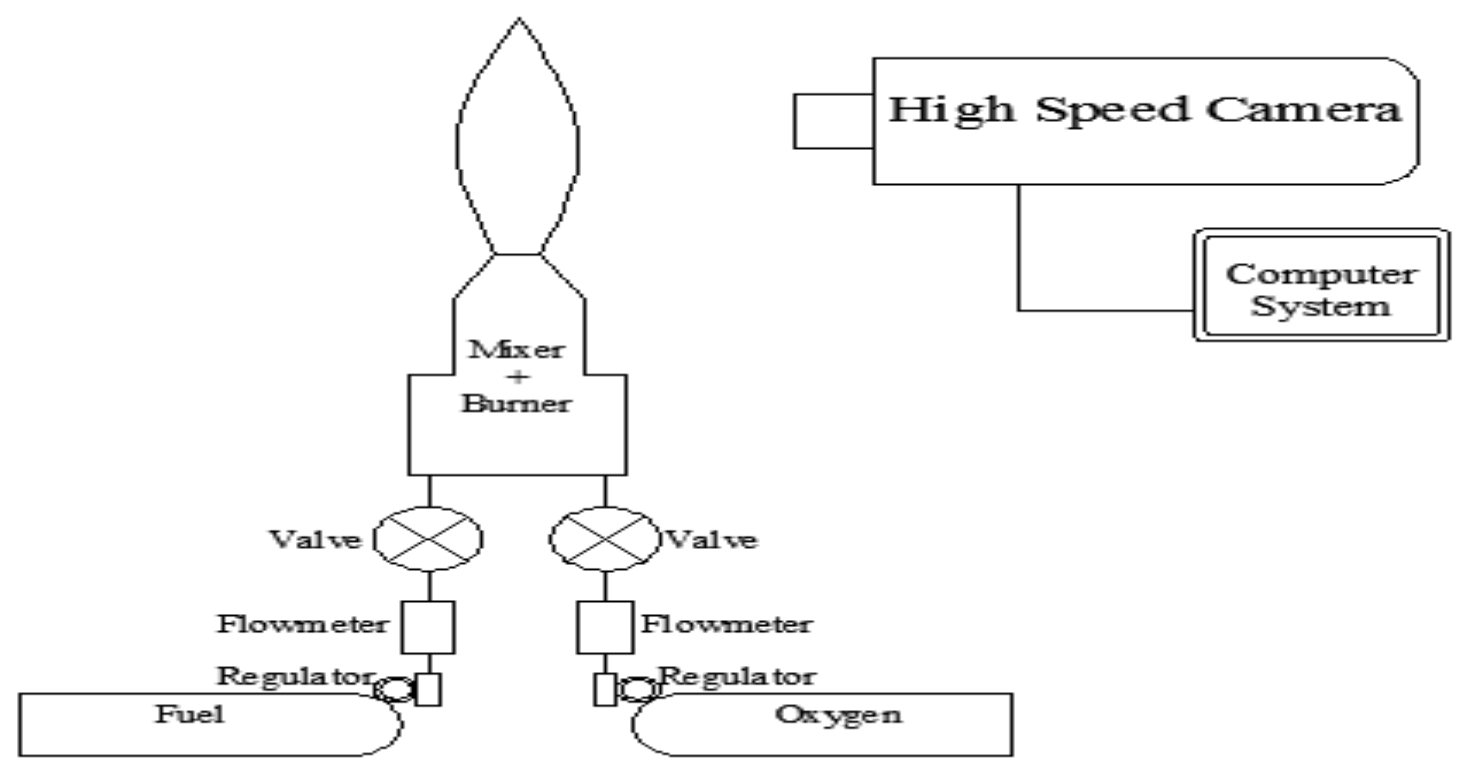

Fig. 1. The experiment schematic diagram 
All the equipment required for the experiment is presented in the Fig. 1, This research's aims were to discover the influences of $\mathrm{N}_{2}$ as it is the second most prevalent inhibitor in biogas by burning stoichiometric fuel mixtures $\left(\mathrm{CH}_{4}\right.$ and $\mathrm{N}_{2}(0 \%-50 \%$ of fuel $\left.)\right)$ and oxygen in an experimental external premixed combustion burner whose nozzle tip diameter (d) was $5 \mathrm{~mm}$. a burner was connected to a hose from the oxygen tank and another hose from the fuel tank. A computer was used to analyze the images from a high speed camera. Two regulators and flowmeters were placed on each tank to monitor the flow supplied to the mixer and burner. The valves were used to stop or open the fluid supply.

In the experiment, each fuel sample and $\mathrm{O}_{2}$ flowed simultaneously into the mixer and burner was ignited after 10 seconds delay. The flowmeter on the fuel tank was also checked for the required flow-rate. The high speed camera was used to record the flames produced. The same steps were repeated for the each $\mathrm{CH}_{4}-\mathrm{N}_{2}$ sample. All the experiments in this research were conducted at ambient temperatures and atmospheric pressure.

\section{Results and Discussion}

The images from the high speed camera were plotted by the computer into separate images. All of those images can be seen at Fig. 2 and Table. 1. The Fig. 2 represents all of the flames produced at various $\mathrm{N}_{2}$ contents from $0 \%$ to $50 \%$ (left to right) respectively.
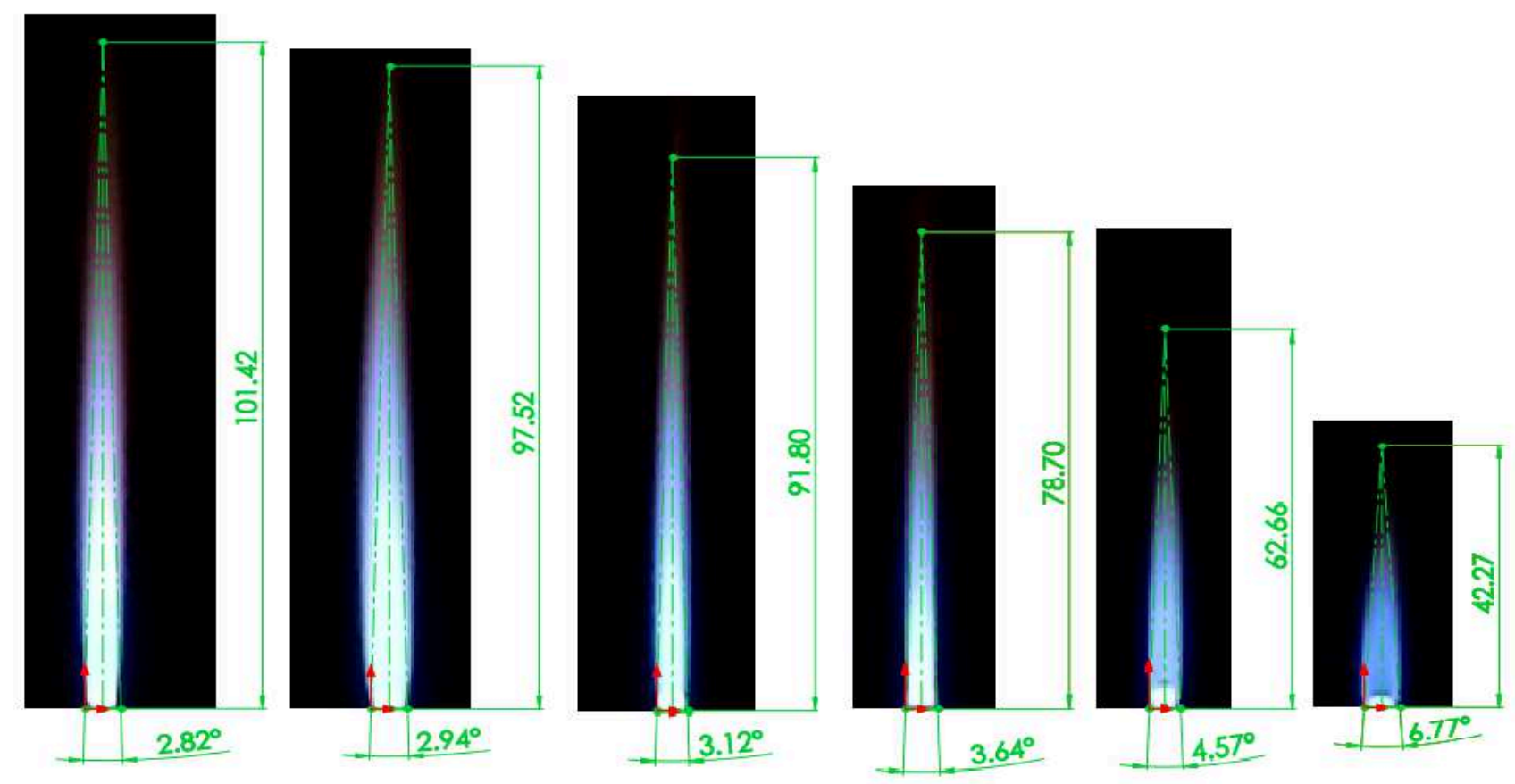

Fig. 2. The flame images of fuels with various $\mathrm{N}_{2}$ content ( $0 \%$ to $50 \%$ respectively)

Table 1. Experiment results

\begin{tabular}{|c|r|r|r|}
\hline $\begin{array}{c}\mathrm{N}_{2} \text { content } \\
\text { in } \%\end{array}$ & $\begin{array}{c}\text { Flame Angle }(\theta) \\
\text { in degree }\end{array}$ & $\begin{array}{c}\text { Flame Height }(\mathrm{H}) \\
\text { in } \mathrm{mm}\end{array}$ & $\begin{array}{c}\text { Dimensionless Flame Height } \\
(\mathrm{H} / \mathrm{d})\end{array}$ \\
\hline 0 & 2.82 & 101.42 & 20.28 \\
\hline 10 & 2.94 & 97.52 & 19.50 \\
\hline 20 & 3.12 & 91.80 & 18.36 \\
\hline 30 & 3.64 & 78.70 & 15.74 \\
\hline 40 & 4.57 & 62.66 & 8.45 \\
\hline 50 & 6.77 & 42.27 & 83 \\
\hline
\end{tabular}


In conclusion, the data in Fig. 2 and Table 1, indicate that $\mathrm{N}_{2}$ significantly affects the combustion process of methane. The greater the $\mathrm{N}_{2}$ content, the shorter the flame height and the lower the dimensionless flame height. Moreover, increasing the $\mathrm{N}_{2}$ content created larger the flame angle. Besides the images in Fig. 2 and data in Table 1, the 3 graphs (Fig. 3, Fig. 4 and Fig. 5) plot the results of flame angles, flame heights, and dimensionless flame heights.

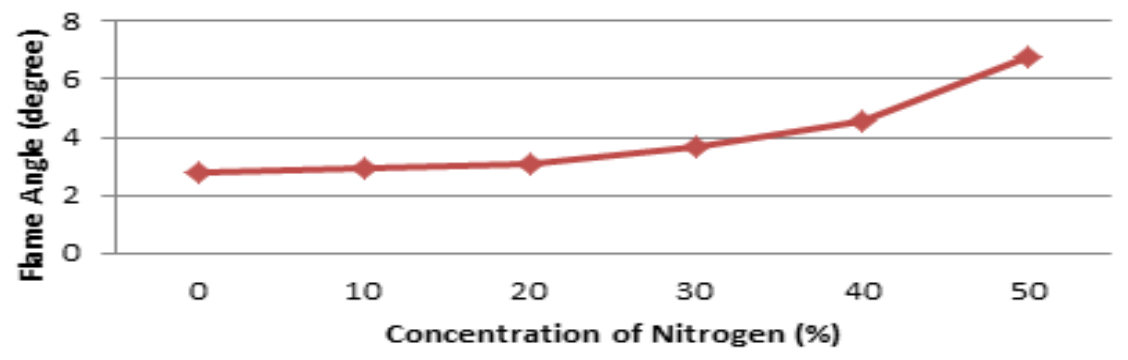

Fig. 3. The Relation between $\mathrm{N}_{2}$ content and flame angle

A big difference occurs between $40 \%$ and $50 \%$ nitrogen concentration as can be seen in Fig. 3 . The mixture with $50 \% \mathrm{~N}_{2}$ in the fuel provides 6.77 degree of flame angle, and the one with $40 \% \mathrm{~N}_{2}$ provides 4.57 degree of flame angle. The difference is 2.2 degree, followed by $0.93,0.53,0.18$, and 0.12 degree of flame angle difference. The smallest difference, 0.12 degree of flame angle, occurs between $0 \%$ and $10 \% \mathrm{~N}_{2}$ of mixtures.

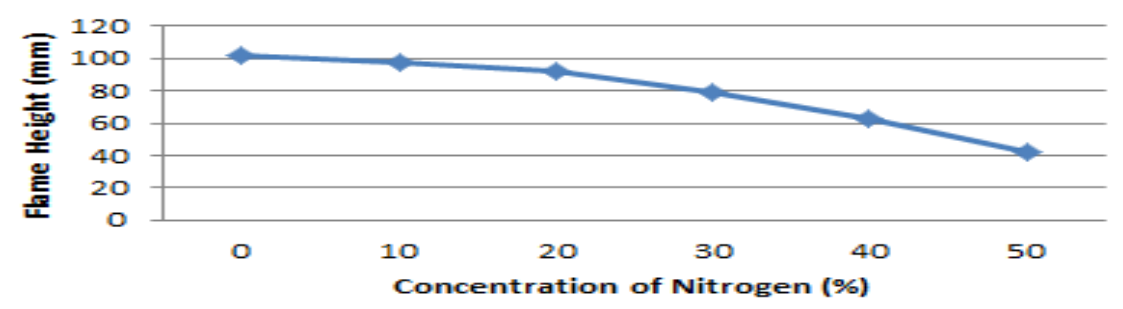

Fig. 4. The relation between $\mathrm{N}_{2}$ content and flame height

The flame height graph results in Fig. 4 tend to go down as $\mathrm{N}_{2}$ concentrations get higher. Again, the biggest difference, which is $20.39 \mathrm{~mm}$, occurs between $40 \%$ and $50 \% \mathrm{~N}_{2}$ of mixtures followed by $16.04 \mathrm{~mm}, 13.1 \mathrm{~mm}, 5.72 \mathrm{~mm}$, and $3.9 \mathrm{~mm}$, which are produced by $30 \%-40 \%, 20 \%-30 \%, 10 \%-20 \%$, $0 \%-10 \% \mathrm{~N}_{2}$ of mixtures respectively.

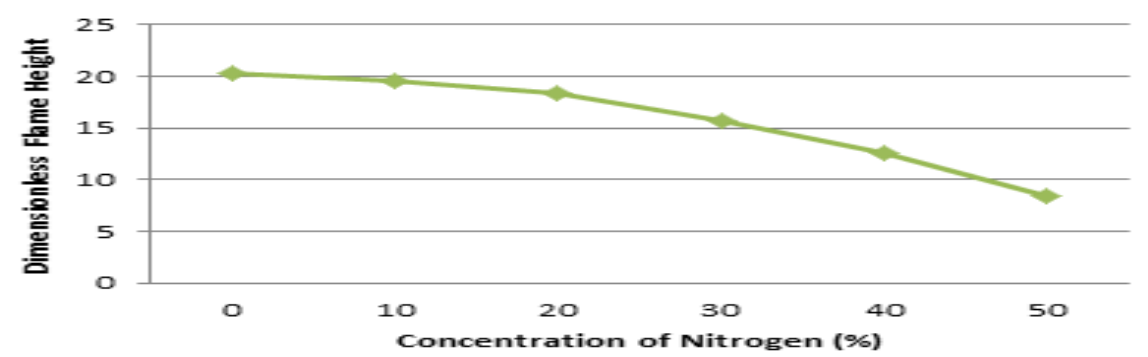

Fig. 5. The relation between $\mathrm{N}_{2}$ content and dimensionless flame height

The dimensionless flame height graph results in Fig. 5 tend to go down as $\mathrm{N}_{2}$ concentrations get higher. The biggest difference, which is 4.08 , occurs between $40 \%$ and $50 \% \mathrm{~N}_{2}$ of mixtures followed by $3.21,2.62,1.14$, and 0.78 , which are produced by $30 \%-40 \%, 20 \%-30 \%, 10 \%-20 \%, 0 \%-10 \% \mathrm{~N}_{2}$ of mixtures respectively.

All the data (Table 1) and figures (Fig. 2 till Fig. 5) show that $\mathrm{N}_{2}$ influenced the flame angle, flame height and dimensionless flame height. The higher the $\mathrm{N}_{2}$ content inside the fuel, the shorter the flame height and the lower the dimensionless flame height. Moreover, increasing the $\mathrm{N}_{2}$ content created larger the flame angle. 


\section{Conclusion}

Nitrogen, which expands the size of the flame angle, performs as an inhibitor in the external combustion process. The higher the $\mathrm{N}_{2}$ content inside the fuel, the shorter the flame height and the lower the dimensionless flame height. Moreover, increasing the $\mathrm{N}_{2}$ content created larger the flame angle. A big difference occurs between $40 \%$ and $50 \%$ nitrogen concentration. The mixture with $50 \%$ $\mathrm{N}_{2}$ provides 6.77 degree of flame angle, and the one with $40 \% \mathrm{~N}_{2}$ provides 4.57 degree of flame angle. The difference is 2.2 degree. The smallest difference, 0.12 degree of flame angle, occurs between $0 \%$ and $10 \% \mathrm{~N}_{2}$ of mixtures. The flame height tends to go down as $\mathrm{N}_{2}$ concentrations get higher. Again, the biggest difference, which is $20.39 \mathrm{~mm}$, occurs between $40 \%$ and $50 \% \mathrm{~N}_{2}$ of mixtures. The dimensionless flame height tends to go down as $\mathrm{N}_{2}$ concentrations get higher. The biggest difference, which is 4.08 degree, occurs between $40 \%$ and $50 \% \mathrm{~N}_{2}$ of mixtures.

\section{Acknowledgement}

Many thanks to Direktorat Jendral Pendidikan Tinggi Kementrian Pendidikan Nasional Republik Indonesia (Hibah Penelitian Fundamental 2014-2015 and Hibah Iptek bagi Mayarakat 2015) and Petra Christian University Indonesia.

\section{References}

[1] H. Kobayashi, H. Hagiwara, H. Kaneko, Y. Ogami, Effects of $\mathrm{CO}_{2}$ dilution on turbulent premixed flames at high pressure and high temperature, Proceedings of the Combustion Institute. 31 (2007) 1451-1458.

[2] H. Kobayashi, K. Seyama, H. Hagiwara, Y. Ogami, Burning velocity correlation of methane/air turbulent premixed flames at high temperature and high pressure, Proceedings of the Combustion Institute. 30 (2005) 827-834.

[3] H. Kobayashi, Experimental study of high pressure turbulent premixed flames, Experimental Thermal and Fluid Science. 26 (2002) 375-387.

[4] X. Chen, Y. Zhang, Y. Zhang, Effects of $\mathrm{CH}_{4}$-Air ratios on gas explosion flame microstructure and propagation behaviour, Energies. 5 (2012) 4132-4146.

[5] C. César, A. Amell, H. Burbano, Laminar burning velocity of natural gas/syngas-air mixture, Dyna. 80 (2013) 136-143.

[6] H. Saroso, I.N.G. Wardana, R. Soenoko, N. Hamidi, Burning characteristics of coconut vapor-air mixtures at premixed combustion, Advanced Studies in Theoretical Physics. 7 (2013) 941.

[7] P. Muthukumar, P. Anand, P. Sachdeva, Performance analysis of porous radiant burner used in LPG cooking stove, International Journal of Energy and Environment. 2 (2011) 367-374

[8] Y. Liang, W. Zeng, E. Hu, Experimental study of the effect of nitrogen addition on gas explotion, Journal of Prevention in The Process Industries. 26 (2013) 1-9.

[9] B. Kashir et al., Experimental study on propane/oxygen and natural gas/oxygen laminar diffusion flames in diluting and preheating conditions, Thermal Science. 16 (2012) 1043-1053.

[10] F. Migliorini, S. De Iuliis, F. Cignoli, G. Zizak, How "flat" is the rich premixed flame produced by your McKenna burner, Combustion and Flame. 153 (2008) 384-393.

[11] C.Y. Wu, K.H. Chen, S.Y. Yang, Experimental study of porous metal burners for domestic stove applications, Energy Conversion and Management. 77 (2014) 380-388.

[12] S. Osami, K. Sakai, Flame length and width produced by ejected propane gas fuel from a pipe, Fire Science and Technology. 1 (1997) 55-63.

[13] W. Anggono, I.N.G. Wardana, M. Lawes, K.J. Hughes, S. Wahyudi, N. Hamidi, Laminar burning characteristics of biogas-air mixtures in spark ignited premix combustion, Journal of Applied Sciences Research. 8 (2012) 4126-4132.

[14] W. Anggono, I.N.G. Wardana, M. Lawes, K.J. Hughes, S. Wahyudi, N. Hamidi, A. Hayakawa, Laminar burning velocity and flammability characteristics of biogas-air mixtures in spark ignited premix combustion, Journal of Physics Conference Series. 423 (2013) 1-7. 
[15] W. Anggono, I.N.G. Wardana, N. Lawes, K.J. Hughes, S. Wahyudi, N. Hamidi, Laminar burning velocity and flammability characteristics of biogas in spark ignited premix combustion at reduced pressure, Applied Mechanics and Materials. 376 (2013) 79-85.

[16] W. Anggono, F.D. Suprianto, T.P. Wijaya, M.S. Tanoto, Behavior of flame propagation in biogas spark ignited premix combustion with carbon dioxide inhibitor, Advanced Materials Research. 1044-1045 (2014) 251-254.

[17] W. Anggono, I.N.G. Wardana, M. Lawes, K.J. Hughes, Effect of Inhibitors on biogas laminar burning velocity and flammability limits in spark ignited premix combustion, International Journal of Engineering and Technology. 5 (2014) 4980-4987.

[18] J.J. Alston, N.A. Dembsey, Evaluation of dimensionless flame height parameters to account for fuel source effects, Fire Safety Science-Proceedings of the Seventh International Symposium. 1 (2003) 569-580. 